\title{
Menurunkan Cacat Crawling pada Keramik Berglasir Putih dengan Metode Six Sigma di PT HSI
}

\author{
Hadi Suprapto \\ Program Studi Teknik Industri, Universitas Indraprasta PGRI \\ hadisuprapto2012@gmail.com
}

\begin{abstract}
Abstrak
Dalam era globalisasi saat ini, perkembangan dalam dunia industri baik dari sektor manufaktur dan jasa telah mengalami perubahan dan perkembangan. Tiap perusahaan saling berkompetisi untuk memenangkan persaingan dan mendapatkan pangsa pasar. Dalam pencapaian visi dan misi, perusahaan terus berupaya untuk meningkatkan produksi dan peningkatan kualitas baik dari sistem manajemen mutu yang diterapkan maupun kualitas dari produk yang dihasilkan.Six sigma merupakan suatu metode dan teknik pengendalian dan peningkatan kualitas menuju target 3,4 kegagalan per sejuta kesempatan (DPMO) untuk setiap transaksi produk barang dan jasa. Jadi six sigma merupakan suatu metode atau teknik pengendalian dan peningkatan kualitas dramatik yang merupakan terobosan baru dalam bidang manajemen kualitas. Dengan menggunakan metode Six Sigma dapat diketahui bahwa kualitas keramik berglasir putih yang diproduksi oleh PT HSI di tahun 2017 berada pada level 2.35 Sigma dengan tingkat kerusakan 198345 cacat untuk sejuta produksi (DPMO). Melalui metode DMAIC, nilai Six Sigma meningkat menjadi 2.55 Sigma dengan tingkat kerusakkan 147749 cacat untuk sejuta produksi. Melalui pendekatan Six Sigma pada penelitian ini cacat crawling dapat diperbaiki dari $7.30 \%$ menjadi $3.55 \%$.
\end{abstract}

Kata Kunci : Kualitas, Keramik, Six Sigma, DMAIC, dan Crawling

\begin{abstract}
In the current of globalization, the development of industry in the word both in manufacturing and servis sector has undergone change and development. Each company and competed to win the competition and market share. In achieving it's vision and mision, the company continues to servucess improve the production and quality managenement controlling and improving the quality to word the target 3,4 failures per million opportinities (DPMO) for each transaction of good and services. Six Sigma is a method or thechnique of controlling and dramatic quality improvement is a new breaktrough in the field of quality management. By using the Six Sigma method, it can be seen that the quality of white glazed ceramics produced by PT HSI in 2017 was at the level of 2.35 Sigma with a defect rate of 198345 for a million production (DPMO). Through the DMAIC method, the value of Six Sigma increased to 2.55 Sigma with a damage rate of 147749 defects for a million production. Through the Six Sigma approach in this study crawling defects can be improved from $7.30 \%$ to $3.55 \%$.
\end{abstract}

Keyword: Quality, Ceramic, Six Sigma, DMAIC, and Crawling

\section{PENDAHULUAN}

Ada empat bidang industri keramik yaitu: tile, tableware, sanitary, dan roof tile. Keramik tableware adalah bagian kebutuhan peralatan rumah tangga berupa cangkir, mangkok, piring dan peralatan meja lainnya yang terbuat dari keramik. Kapasitas produksi di Indonesia berkisar 350 juta buah/tahun. Beberapa industri dalam produksi ini fokus untuk di ekspor.

Berdasarkan data dari ASAKI di www.asaki.or.id jumlah perusahaan yang memproduksi keramik tableware di Indonesia yang sudah terdaftar SNI ada 17. Perusahaan keramik tableware tersebut antara lain PT Sango, PT Hangkook, PT Narumi, PT Lucky, PT SKI, PT Indoporcelain, PT HSI dan beberapa 
perusahaan lainnya. Sebagai salah satu perusahaan keramik tableware, PT HSI dituntut untuk mampu berkompetisi dengan perusahaan sejenis dengan melakukan perbaikan kualitas.

Kualitas merupakan kunci keunggulan bersaing (competitive advantage), yaitu kemampuan sebuah perusahaan untuk mencapai keunggulan pasar. Salah satu perbaikan (improvement) kualitas adalah mengurangi kesalahan atau cacat (defect). Harapan dari proses perbaikan kualitas yang dilakukan oleh PT HSI adalah meningkatnya profit perusahaan dan dapat mengambil pangsa pasar yang besar karena menawarkan produk berkualitas tinggi. Untuk jangka panjang, keunggulan bersaing yang terjaga akan menghasilkan kinerja di atas rata-rata [2].

Berdasarkan sumber data internal PT HSI, persentase produksi barang berglasir putih di tahun 2017 mencapai rata-rata $24.9 \%$ dari total kurang lebih 300 warna glasir yang diproduksi. Sementara untuk persentase kualitas satu (KW1) keramik tableware dengan glasir putih periode Januari sampai Desember 2017 adalah 80.17\%. Nilai ini belum mencapai KPI (Key Performance Indicator) yang ditargetkan oleh manajemen yaitu $83 \%$.

Berdasarkan data internal perusahaan diketahui bahwa dalam periode Januari sampai Desember 2017 tahapan proses glazing merupakan urutan pertama penyebab terjadinya cacat dengan persentase $9.02 \%$ atau $45.4 \%$ dari total seluruh cacat yang muncul.

Alasan digunakannya pendekatan metode Six Sigma untuk proses perbaikan kualitas yang dilakukan di PT HSI adalah:

1. Metode Six Sigma selalu berpikir dalam kerangka proses bisnis utama serta kebutuhan pelanggan dengan tetap berfokus pada tujuan strategis perusahaan.

2. Menekankan sistem pengukuran yang bisa dikuantifikasi, seperti cacat per satu juta kemungkinan (defects per million opportunities $=d p m o$ ) yang bisa diterapkan di setiap bagian perusahaan: produksi, rekayasa, administrasi, peranti lunak dan lain-lain.

3. Memastikan bahwa sistem pengukuran yang tepat teridentifikasi di awal setiap proses serta memastikan bahwa sistem tersebut berfokus pada pencapaian bisnis, sehingga dapat memberikan sistem insentif dan akuntabilitas.

\section{Kajian Teori}

Kualitas merupakan hal utama yang mempengaruhi pertimbangan konsumen dalam membeli suatu produk. Singkatnya kualitas merupakan faktor kunci dalam menentukan pertumbuhan, perkembangan dan kelangsungan hidup suatu perusahaan, khususnya pada era sekarang ini. Definisi kualitas sangatlah bervariasi, mengacu pada pakar kualitas, menyebutkan kualitas adalah sebagai kemampuan suatu produk atau jasa untuk secara konsisten memenuhi atau melebihi ekspektasi pelanggan [6]. Selain itu kualitas oleh pakar kualitas didefinisikan sebagai berikut:

a. Kualitas adalah kesesuaian dengan tujuan dan manfaatnya (Juran).

b. Kualitas harus bertujuan memenuhi kebutuhan pelanggan sekarang dan di masa mendatang (Deming).

c. Kualitas merupakan keseluruhan karakteristik produk dan jasa meliputi marketing, engineering, manufacture, dan maintanance, dimana produk dan jasa tersebut dalam pemakaiannya akan sesuai dengan kebutuhan dan harapan pelanggan (Feigenbaum).

\section{Konsep Dasar Six Sigma}

Pada dasarnya pelanggan akan puas apabila mereka menerima nilai yang mereka harapkan. Apabila produk (barang/jasa) diproses pada tingkat kinerja kualitas Six Sigma, perusahaan boleh mengharapkan 3,4 kegagalan per sejuta kesempatan (DPMO) atau bahwa 99,99966 persen dari apa yang diharapkan pelanggan akan ada dalam produk (barang /jasa). Dengan demikian, Six Sigma dapat dijadikan ukuran target kinerja ukuran proses industri tentang bagaimana baiknya suatu proses transaksi suatu produk antara pemasok (industri) dan pelanggan (pasar). Semakin tinggi target sigma yang dicapai, semakin baik kinerja proses industri. Sehingga 6-sigma otomatis lebih baik dari 4-sigma dan 3-sigma. Six Sigma juga 
dapat dianggap sebagai strategi terobosan yang memungkinkan perusahaan melakukan peningkatan luar biasa di tingkat bawah dan sebagai pengendali proses industri yang berfokus pada pelanggan dengan mempehatikan kemampuan proses [1,3].

\section{Metode DMAIC dalam Six Sigma}

Dalam mengerjakan suatu proyek yang berkaitan dengan Six Sigma atau berkaitan dengan perbaikan kualitas dikenal kerangka berpikir yang dinamakan Define-Measure-Analyze-Improve-Control (DMAIC). Sangat penting untuk mengikuti kerangka berpikir ini sehingga permasalahan yang akan diselesaikan benar-benar akan memberikan perbaikan yang menyeluruh kepada proses dan keuntungan perusahaan [5].

\section{METODE PENELITIAN}

Metode yang digunakan dalam penelitian ini adalah metode penelitian kuantitatif, yaitu meneliti populasi atau sampel secara statistik kemudian diolah dan dianalisa untuk diambil kesimpulan. Pada penelitian ini yang menjadi variabel adalah defect. Defect adalah kegagalan untuk memenuhi persyaratan pelanggan atau kinerja standar. Six Sigma merupakan salah satu metode yang berfokus pada proses dan pencegahan cacat (defect) [2]. Jenis data yang digunakan peneliti dalam penelitian adalah data primer dan sekunder. Pengumpulan data dilakukan dengan cara penelitian lapangan (Field Research) dan studi kepustakaan (Library Research). Populasi sampling dalam tesis ini menggunakan sampling jenuh. Populasi dalam penelitian ini adalah produk keramik yang mengalami rusak/ cacat selama bulan Januari 2017 sampai Desember 2017 yang didata oleh bagian Quality Control.

Menggunakan Metode DMAIC dalam Six Sigma. Define adalah fase menentukan masalah, menetapkan persyaratan-persyaratan pelanggan dan membangun tim. Statistik yang digunakan dalam fase ini diagram cause \& effect dan diagram pareto [6]. Dalam melakukan pengendalian kualitas secara statistik, langkah pertama yang akan dilakukan adalah mengetahui data-data yang mendukung pemecahan masalah. Setelah diketahui data tersebut maka selanjutnya dilakukan pengukuran pareto berdasarkan tingkat cacat dengan menggunakan minitab ver.16. Langkah selanjutnya adalah mengukur tingkat Sigma. Pada tahap Measure juga dihitung nilai Cost of Poor Quality (COPQ) untuk mengetahui elemen biaya kualitas yang timbul selama proses produksi akibat ketidaksesuaian produk terhadap spesifikasi yang diinginkan [4]. Analyze merupakan tahapan ketiga dalam metode Six Sigma, tahapan yang dilakukan adalah menganalisis lebih jauh Pareto Defect. Alat yang digunakan :

1. Diagram sebab akibat memperlihatkan hubungan antara permasalahan yang dihadapi dengan kemungkinan penyebabnya serta faktor-faktor yang mempengaruhinya.

2. Menentukan RPN (Risk Priority Number) dengan FMEA

Analysis dengan Uji kritikal faktor bertujuan untuk memastikan apakah faktor kritikal itu merupakan faktor vital. Uji yang dilakukan adalah uji normality dan uji hipotesa menggunakan ANOVA. Software yang digunakan adalah Minitab Ver.16. Improve adalah fase meningkatkan proses (x) dan menghilangkan sebab-sebab cacat. Pada fase measure telah ditetapkan variabel faktor (x) untuk masing-masing variabel respons (y). Pada fase improve dipilih strategi untuk peningkatan variabel faktor [4]. Control Merupakan tahap analisis terakhir dari proyek Six sigma yang menekankan pada pendokumentasian dan penyebarluasan dari tindakan yang telah dilakukan. Control adalah fase mengontrol kinerja proses (X) dan menjamin cacat tidak muncul [6].

\section{HASIL DAN PEMBAHASAN}

\section{Define}

Berdasarkan data internal perusahaan diketahui bahwa dalam periode Januari sampai Desember 2017 tahapan proses glazing merupakan urutan pertama penyebab terjadinya cacat dengan persentase $9.02 \%$ atau $45.4 \%$ dari total seluruh cacat yang muncul. 


\section{Measure}

Defect/cacat yang terjadi pada tahapan produksi glasir putih pada periode Januari sampai dengan Desember 2017, terjadi pada proses glazing. Rincian defect yang terjadi pada proses glazing diuraikan dalam Tabel 1.

Tabel 1. Defect/Cacat yang Terjadi pada Tahap Glazing

\begin{tabular}{cccc}
\hline Jenis Kerusakkan & Persentase & \% & \% Kum \\
\hline Crawling & $7.30 \%$ & $80.9 \%$ & $80.9 \%$ \\
\hline Glasir Kurang Rata & $0.70 \%$ & $7.8 \%$ & $88.7 \%$ \\
\hline Kotoran Saggar & $0.60 \%$ & $6.7 \%$ & $95.3 \%$ \\
\hline Kotoran Warna & $0.24 \%$ & $2.7 \%$ & $98.0 \%$ \\
\hline Lipatan Pada Kaki & $0.10 \%$ & $1.1 \%$ & $99.1 \%$ \\
\hline Logo Pad Rusak & $0.08 \%$ & $0.9 \%$ & $100.0 \%$ \\
\hline Total & $9.02 \%$ & $100.0 \%$ & \\
\hline
\end{tabular}

Sumber: PT HSI, 2018

Berdasarkan data pada Tabel 1, terlihat defect crawling adalah pareto untuk kerusakkan di area glazing. Pengertian crawling adalah terlepasnya glasir dari body keramik saat proses pembakaran (gambar.2).

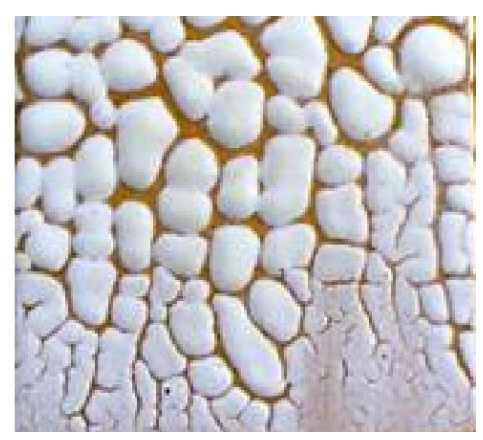

Gambar 2. Defect Crawling

\section{Mengukur Tingkat DPMO dan Level Sigma}

Hasil Pengukuran Tingkat DPMO Level Sigma dapat dilihat dalam Tabel 2.

Cara menentukan DPMO, DPU dan Nilai Sigma adalah sebagai berikut:

$$
\begin{gathered}
\text { DPU }=\frac{\text { Banyak Cacat }}{\text { Unit yang diperiksa }} \\
\text { DPMO }=\frac{\text { Banyak Cacat }}{\text { Unit yang diperiksa }} X 1.000 .000 \\
\text { Nilai Sigma }=\text { NORMSINV }\left(\frac{1000000-D P M O}{1000000}\right)+1.5
\end{gathered}
$$

Tabel 2. Perhitungan Nilai Sigma Produksi Glasir Putih Tahun 2017

\begin{tabular}{cccccccc}
\hline $\begin{array}{c}\text { Bulan } \\
\text { (Tahun 2017) }\end{array}$ & $\begin{array}{c}\text { Jumlah Produksi } \\
\text { (PCS) }\end{array}$ & $\begin{array}{c}\text { Jumlah } \\
\text { Defect (PCS) }\end{array}$ & DPU & CTQ & DPO & DPMO & $\begin{array}{c}\text { Sigma } \\
\text { Per Bulan }\end{array}$ \\
\hline Januari & 139351 & 34559 & 0.2479997 & 1 & 0.2479997 & 248000 & 2.18 \\
\hline
\end{tabular}




\begin{tabular}{ccccccccc}
\hline Pebruari & 199326 & 37496 & 0.1881139 & 1 & 0.1881139 & 188114 & 2.38 \\
\hline Maret & 264608 & 52936 & 0.2000544 & 1 & 0.2000544 & 200054 & 2.34 \\
\hline April & 231789 & 42894 & 0.1850562 & 1 & 0.1850562 & 185056 & 2.40 \\
\hline Mei & 271157 & 53481 & 0.1972326 & 1 & 0.1972326 & 197233 & 2.35 \\
\hline Juni & 285792 & 58324 & 0.2040785 & 1 & 0.2040785 & 204078 & 2.33 \\
\hline Juli & 229051 & 47442 & 0.2071242 & 1 & 0.2071242 & 207124 & 2.32 \\
\hline Agustus & 212481 & 39891 & 0.1877391 & 1 & 0.1877391 & 187739 & 2.39 \\
\hline September & 239348 & 47152 & 0.1970019 & 1 & 0.1970019 & 197002 & 2.35 \\
\hline Oktober & 338589 & 61558 & 0.1818074 & 1 & 0.1818074 & 181807 & 2.41 \\
\hline November & 157598 & 31821 & 0.2019125 & 1 & 0.2019125 & 201912 & 2.33 \\
\hline Desember & 217460 & 45145 & 0.2076014 & 1 & 0.2076014 & 207601 & 2.31 \\
\hline Total & 2786550 & 552699 & 0.1983453 & 1 & 0.1983453 & 198345 & 2.35 \\
\hline
\end{tabular}

\section{Cost of Poor Quality (COPQ)}

$C O P Q$ merupakan elemen biaya kualitas yang timbul selama proses produksi akibat ketidaksesuaian produk terhadap spesifikasi yang ditetapkan oleh konsumen. Pada penelitian ini biaya kualitas yang dihitung adalah produk kw2/reject di luar batas spesifikasi yang ditetapkan oleh perusahaan. Perhitungan biaya kualitas untuk produksi glasir putih tercantum dalam Tabel 3. Berdasarkan perhitungan terlihat bahwa $C O P Q$ untuk satu tahun sebesar Rp. 1,184,040,000. Asumsi harga 1 pcs Rp. 15.000,-.

\section{Tabel 3. COPQ Per Tahun untuk Produksi Glasir Putih}

\begin{tabular}{cccccc}
\hline $\begin{array}{c}\text { Produksi } \\
\text { perbulan (pes) }\end{array}$ & $\begin{array}{c}\text { Jumlah Defect } \\
\text { Aktual (pes) }\end{array}$ & $\begin{array}{c}\text { Jumlah Defect } \\
\text { Maksimal (pes) }\end{array}$ & $\begin{array}{c}\text { Selisih } \\
\text { (pes) }\end{array}$ & $\begin{array}{c}\text { COPQ per } \\
\text { Bulan (Rp.) }\end{array}$ & $\begin{array}{c}\text { COPQ per Tahun } \\
\text { (Rp.) }\end{array}$ \\
\hline 232213 & 46058 & 39480 & 6578 & $98,670,000$. & $1,184,040,000$. \\
\hline
\end{tabular}

\section{Analisis}

Analisa lebih lanjut mengenai faktor penyebab defect dilakukan dengan metoda FMEA, sehingga diperoleh nilai RPN untuk masing-masing faktor Penyebab yang dilampirkan dalam Tabel 4.

Tabel 4. Analisa Penyebab Potensial Defect Crawling dengan FMEA

\begin{tabular}{cclcccc}
\hline No & Faktor & \multicolumn{1}{c}{ Penyebab Potensial } & S & O & D & RPN \\
\hline 1 & Material & Residu glasir terlalu tinggi & 10 & 8 & 7 & 560 \\
\hline 2 & Material & Umur glasir terlalu lama & 9 & 7 & 7 & 441 \\
\hline 3 & Material & Glasir mudah mengendap & 9 & 6 & 7 & 378 \\
\hline 4 & Metoda & Aplikasi glasir tidak nyaman & 8 & 5 & 7 & 280 \\
\hline 5 & Mesin & Kecepatan konvier tidak sama & 7 & 5 & 7 & 245 \\
\hline 6 & Manusia & Operator baru belum beradaptasi & 7 & 4 & 7 & 196 \\
\hline 7 & Lingkungan & Ada kontaminasi minyak dan lemak & 7 & 3 & 6 & 126 \\
\hline 8 & Lingkungan & Temperatur lingkungan tinggi & 5 & 5 & 5 & 125 \\
\hline & Keterangan: S: Severity, O: Occurrence & D: Detection & &
\end{tabular}

Berdasarkan Tabel 4 diperoleh krititikal faktor untuk cacat glazing sebanyak 8 macam. Untuk penelitian kali ini kita hanya mengambil 2 kritikal faktor dengan nilai RPN tertinggi untuk diuji lebih lanjut. Kritikal faktor tersebut berasal dari faktor material meliputi residu glasir (nilai RPN 560) dan umur glasir (nilai RPN 441).

\section{Uji kritikal faktor}

Uji dilakukan dengan menguji normalitas data dan uji hipotesis rata-rata populasi menggunakan ANOVA (One Way Analisis of Variance) dengan satu variabel faktor. 


\section{Faktor Material, Residu Glasir (Nilai RPN 560)}

Standar residu untuk glasir putih yang digunakan saat ini adalah $0.15 \%$ dengan batas bawah $0.10 \%$ dan batas atas $0.20 \%$. Untuk mengetahui apakah standar residu saat ini sudah cukup optimal maka dilakukan eksperimen dengan menguji menggunakan glasir yang di setting dengan residu glasir $0.20 \%$ (lebih tinggi) dan $0.10 \%$ (lebih rendah). Uji dilakukan menggunakan 10 item yang berbeda.

$\mathrm{H}_{0}$ : tidak ada perbedaan jumlah cacat crawling dari 3 variasi residu glasir $\mathrm{H}_{1}$ : ada perbedaan jumlah cacat crawling dari 3 variasi residu glasir

Karena hasil uji anova pada eksperimen menunjukkan nilai $\mathrm{P}_{\text {value }}(0.000)<$ koefisien signifikansi, $\alpha$ (0.05), maka $\mathrm{H}_{0}$ ditolak. Jadi ada perbedaan rata-rata tingkat cacat crawling akibat adanya variasi ukuran residu glasir.

Hasil main effect plot crawling terhadap variasi residu terlihat pada Gambar 3. Berdasarkan ini terlihat bahwa residu glasir dengan nilai $0.1 \%$ memilki angka cacat crawling yang paling rendah dibandingkan 2 variasi ukuran residu yang lain.

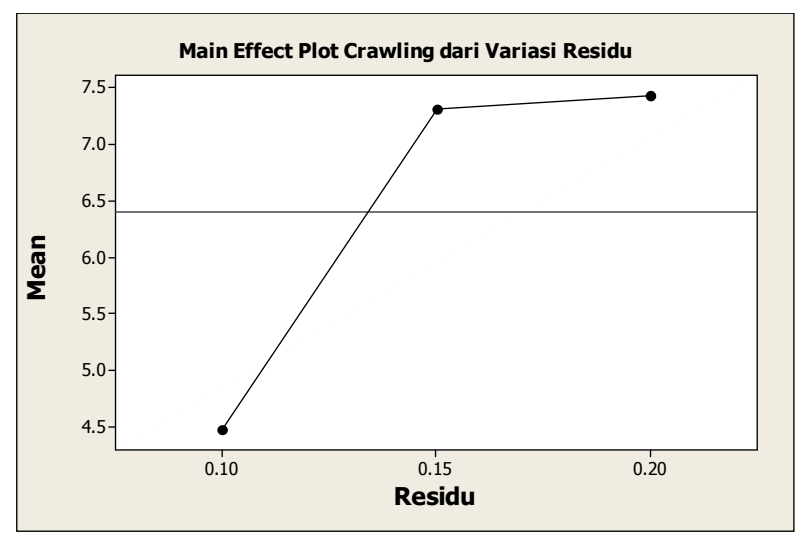

Gambar 3. Main Effect Plot Crawling dari Hasil Ekperimen Variasi Residu Sumber: Data Perhitungan, 2018

Faktor Material, Umur Glasir (Nilai RPN 441)

Standar umur untuk glasir putih yang digunakan saat ini adalah maksimal 21 hari. Untuk mengetahui apakah standar umur glasir saat ini sudah cukup optimal maka dilakukan eksperimen dengan menguji menggunakan glasir yang di setting dengan umur 28 hari (lebih tinggi) dan 14 hari (lebih rendah). Uji dilakukan menggunakan 10 item yang berbeda.

Hipotesis yang digunakan dalam eksperimen adalah:

$\mathrm{H}_{0}$ : tidak ada perbedaan jumlah cacat crawling dari 3 variasi umur glasir

$\mathrm{H}_{1}$ : ada perbedaan jumlah cacat crawling dari 3 variasi umur glasir

Karena hasil uji anova pada eksperimen menunjukkan nilai $\mathrm{P}_{\text {value }}(0.000)<$ koefisien signifikansi, $\alpha$ (0.05), maka $\mathrm{H}_{0}$ ditolak. Jadi ada perbedaan rata-rata tingkat cacat crawling akibat adanya variasi umur glasir.

Hasil main effect plot crawling terhadap variasi umur glasir terlihat pada Gambar 4. Berdasarkan kedua gambar ini terlihat bahwa umur glasir 14 hari memilki angka cacat crawling yang paling rendah dibandingkan 2 variasi umur glasir yang lain. 


\section{Improvement}

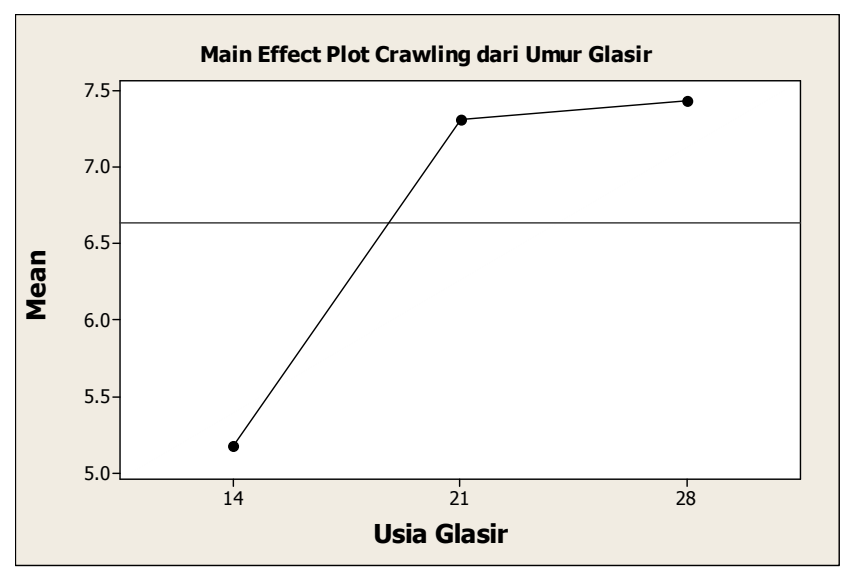

Gambar 4. Main Effect Plot Crawling dari Umur Glasir Sumber: Perhitungan, 2018

Proses improvement dilakukan dengan melakukan setting residu glasir pada $0.10 \%$ dan umur glasir maksimal 14 hari. Uji dilakukan menggunakan 10 item yang berbeda. Hasil uji menunjukkan rata-rata cacat crawling dengan setting residu glasir pada $0.10 \%$ dan umur glasir maksimal 14 hari adalah $3.31 \%$. Hasil uji ini dicoba diterapkan dalam skala mass pro dan dilakukan evaluasi setiap bulan. Hasil improvement terlihat di bulan Januari sampai dengan Juni 2018 dengan adanya kenaikkan kualitas seperti yang terlihat dalam Tabel 8.

Tabel 8. Perhitungan Nilai Sigma Produksi Glasir Putih Tahun 2018

\begin{tabular}{ccccccc}
\hline $\begin{array}{c}\text { Bulan } \\
\text { (Tahun } \\
\text { 2018) }\end{array}$ & $\begin{array}{c}\text { Jumlah } \\
\text { Produksi }\end{array}$ & $\begin{array}{c}\text { Jumlah } \\
\text { Defect }\end{array}$ & $\begin{array}{c}\text { KW } \\
\text { KW }\end{array}$ & DPO & DPMO & $\begin{array}{c}\text { Sigma } \\
\text { Per Bulan }\end{array}$ \\
\hline Januari & 177500 & 25000 & $85.92 \%$ & 0.140845 & 140845 & 2.58 \\
\hline Pebruari & 185753 & 24672 & $86.72 \%$ & 0.132822 & 132822 & 2.61 \\
\hline Maret & 177812 & 28540 & $83.95 \%$ & 0.160507 & 160507 & 2.49 \\
\hline April & 178500 & 25800 & $85.55 \%$ & 0.144538 & 144538 & 2.56 \\
\hline Mei & 167588 & 24582 & $85.33 \%$ & 0.146681 & 146681 & 2.55 \\
\hline Juni & 187500 & 27581 & $85.29 \%$ & 0.147099 & 147099 & 2.55 \\
\hline Total & 1074653 & 156175 & $85.23 \%$ & 0.147749 & 147749 & 2.55 \\
\hline \multicolumn{7}{c}{ Sumber: Hasil Perhitungan 2018} \\
\end{tabular}

Untuk persentase kerusakan setelah perbaikan per area glazing dapat dilihat pada Tabel 9. dan untuk perbaikan COPQ terdapat dalam Tabel 10.

Tabel 9. Persentase Penurunan Kerusakan Crawling

\begin{tabular}{cccc}
\hline Jenis Defect & Sebelum Perbaikan & Setelah Perbaikan & Penurunan Defect \\
\hline Crawling & $7.30 \%$ & $3.55 \%$ & $48.63 \%$ \\
\hline
\end{tabular}

Sumber: Data Perhitungan 2018 


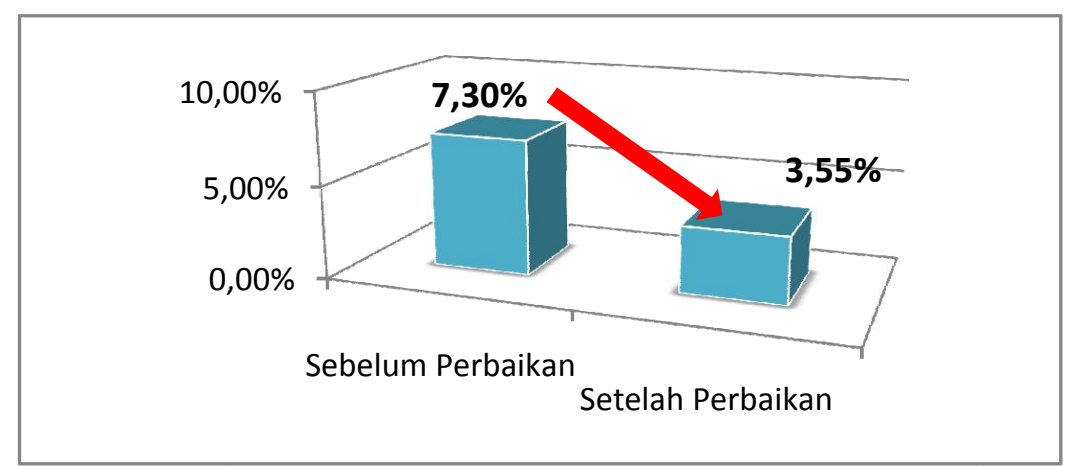

Gambar 5. Penurunan Defect Crawling

Tabel 10. Tabel Perhitungan COPQ Setelah Perbaikan

\begin{tabular}{cccccc}
\hline $\begin{array}{c}\text { Produksi } \\
\text { perbulan (pcs) }\end{array}$ & $\begin{array}{c}\text { Jumlah Reject } \\
\text { Aktual (pes) }\end{array}$ & $\begin{array}{c}\text { Jumlah Reject Maximal } \\
\text { (pcs) }\end{array}$ & $\begin{array}{c}\text { Selisih } \\
(\text { pcs) }\end{array}$ & $\begin{array}{c}\text { COPQ per } \\
\text { Bulan (Rp.) }\end{array}$ & $\begin{array}{c}\text { COPQ per } \\
\text { Tahun (Rp.) }\end{array}$ \\
\hline 179109 & 26454 & 30449 & -3994 & $(59,911,905)$ & $(718,942,857)$ \\
\hline
\end{tabular}

Sumber: Hasil Perhitungan

Dari Tabel 9 terlihat terjadi penurunan defect crawling sebesar $48.63 \%$. Sementara untuk nilai COPQ setelah perbaikan mengalami surplus sebesar Rp. 59,911,905 per bulan ditunjukkan dalam Tabel 10.

\section{Control}

Untuk pengendalian cacat crawling dilakukan setting residu glasir pada nilai $0.10 \%$ dan pemakaian glasir maksimal 14 hari. Hasil yang diperoleh selama 6 bulan defect rata rata crawling 3.55\%.

\section{SIMPULAN}

Berdasarkan penelitian yang sudah dilakukan di PT HSI, maka nilai Six Sigma perusahaan saat ini dengan kinerja proses selama bulan Januari sampai Desember 2017 untuk keramik tableware berglasir putih berada pada tingkat 2.35 Sigma dengan rata-rata kualitas $80.17 \%$ serta nilai DPMO 198345. Pareto kerusakkan terjadi pada area proses glazing. Jenis cacat yang terjadi di area glazing yaitu Crawling (7.3\%), Glasir Kurang Rata (0.7\%), Kotoran Saggar (0.6\%), Kotoran Warna (0.24\%), Lipatan Pada Kaki (0.1\%), Logo Pad Rusak (0.08\%).

Upaya untuk mengurangi defect di tahap glazing khususnya jenis crawling dilakukan dengan melakukan setting residu glasir dari 0.15 menjadi $0.10 \%$ dan membatasi umur pemakaian glasir maksimal 14 hari. Perbaikan kualitas dilakukan dengan metoda DMAIC melaui pendekatan Six Sigma. Hasil perbaikan diperoleh peningkatan nilai Sigma pada tingkat 2.55 atau lebih tinggi 3\% dari nilai yang ditargetkan perusahaan. Pencapaian kualitas rata-rata 85.23\% dengan nilai DPMO 147749. Hal ini menunjukkan metoda DMAIC dengan pendekatan Six Sigma dapat digunakan untuk melakukan perbaikan kualitas di PT HSI.

Perbaikan kualitas melalui pendekatan Six Sigma dengan metoda DMAIC merupakan metoda ilmiah yang dapat diterapkan secara praktis di lingkungan industri khususnya industri keramik. Menurunkan tingkat cacat pada produk keramik tableware berglasir putih masih belum selesai, mengingat defect crawling masih bernilai 3.55\%. Untuk itu perlu dilakukan proses improvement lebih lanjut untuk dapat mengurangi defect ke tingkat 0 . 


\section{UCAPAN TERIMAKASIH}

Penulis mengucapkan terimakasih kepada seluruh rekan kerja di PT HSI dan rekan pengajar di Unindra PGRI Jakarta yang telah mendukung penulisan artikel ini. Semoga tulisan bermanfaat untuk kita semua.

\section{DAFTAR PUSTAKA}

[1] ArunKumar, G., \& Dillibabu, R. (2016). Design and application of new quality improvement model: kano lean six sigma for software maintenance Project. Arabian Journal for Science and Engineering, 41(3), 997-1014.

[2] Evans James, R., \& Lindsay, W. M. (2005). An Introduction to Six Sigma \& Process Improvement (Book and CD).

[3] Gaspersz V.,\& Fontana A. (2011). Lean Six Sima for Manufacturing and Service Industries, Penerbit Vinchiristo Publication, Bogor.

[4] Hendradi, T. C. (2006). Statistik six sigma dengan Minitab. Panduan Cerdas Inisiatif Kualitas. ANDI OFFSET. Yogyakarta.

[5] Rajak, A. K., Niraj, M., \& Kumar, S. (2016). In Pursuit of Lean Six Sigma: A Systematic Review. International Journal of Applied Engineering Research, 11(1), 547-556.

[6] Stevenson, W., \& Chuong, S. C. (2014). Operation Management: An Asian Perspective, McGrawHill Education, New York. 